\title{
PETA DAN KETERPAKAIAN KOLEKSI KARYA SASTRA DI PERPUSTAKAAN FAKULTAS ILMU BUDAYA UNIVERSITAS LANCANG KUNING
}

\author{
Afdhal Zikrillah*), Rosman $\mathbf{H}^{* *}$ ) \\ Fakultas Ilmu Budaya, Universitas Lancang Kuning, Pekanbaru Indonesia \\ email: afdalsulita@gmail.com*),rosmanpanam@gmail.com**)
}

Naskah diterima: 1 Juni; direvisi: 7 Juni; disetujui: 10 Juni 2019.

\begin{abstract}
Abstrak
Tujuan penelitian ini adalah untuk mengetahui bagaiman peta dan keterpakaian koleksi karya sastra di perpustakaan Fakultas Ilmu Budaya (FIB). Metode yang digunakan dalam penelitian ini adalah metode kualitatif. Hasil dari penelitian menunjukan bahwa peta koleksi karya sastra yang ada di Perpustakaan FIB Unilak terdiri dari sastra kreatif berjumlah $89,25 \%$ atau 357 judul dan sastra ilmiah berjumlah $10,75 \%$ atau 43 judul. Jenis koleksi sastra ilmiah bidang Monodisiplin merupakan koleksi terbayak yaitu 72,09\% atau 31 judul, dan bidang multidisiplin hanya $27,21 \%$ atau 43 judul. Dilihat dari genre koleksi Prosa yang ada di perpustakan FIB UNILAK, jenis novel merupakan koleksi terbanyak yaitu 54,36\% atau 131 judul dan jenis cerpen hanya 45,64\% atau 110 judul. Dilihat dari koleksi sastra ilmiah bidang Monodisiplin, koleksi jenis teori merupakan koleksi terbanyak yaitu 80,65\% atau 25 judul, koleksi jenis sejarah 16,13\% atau 5 judul, dan koleksi jenis kritik hanya $3,23 \%$ atau 1 judul. Bidang multidisiplin yang ada di Perpustakaan FIB UNILAK, koleksi Sosiologi 83,33\% atau 10 judul, jenis piskologi $\quad$ 0,00\% atau 0 judul, dan koleksi jenis antropoloigi hanya $16,67 \%$ atau 2 judul. Sedangkan dari keterpakaian koleksi karya Sastra di Perpustakaan FIB UNILAK yaitu dari 400 judul $(9,5 \%)$ dan 766 eksemplar (13,8\%). Jumlah keterpakaian koleksi karya sastra keseluruhan yaitu 16,19\% atau 124 kali keterpakaian. Dilihat dari sastra kreatif jenis prosa 95 judul yang digunakan atau 76,61\% dan jenis puisi hanya 8 judul atau 6,45 \% dan drama tidak ada judul terpakai sama sekali. Dilihat dari keterpakaian karya sastra ilmiah bidang ilmiah monidisiplin 19 judul yang terpakai atau 15,32\% dan bidang multidisiplin hanya 2 judul yang terpakai atau $1,61 \%$.
\end{abstract}

Kata Kunci : Peta, Keterpakaian, Karya Sastra, Perpustakaan FIB

\begin{abstract}
The purpose of this study was to determine how the map and the use of a collection of literary works in the library of the Faculty of Humanities (FIB). The method used in this research is a qualitative method. The results of the study show that the map of the collection of literary works in the Unilak FIB Library consists of creative literature totaling $89.25 \%$ or 357 titles and scientific literature totaling $10.75 \%$ or 43 titles. Types of scientific literary collections in the field of Monodiscipline are the largest collections of $72.09 \%$ or 31 titles, and the multidisciplinary field is only $27.21 \%$ or 43 titles. From the Prose collection genre in the UNILAK FIB library, the type of novel is the largest collection, which has $54.36 \%$ or 131 titles and the type of short stories is only $45.64 \%$ or 110 titles. As can be seen from the collection of scientific literature in the field of Monodiscipline, the collection of types of theories is the largest collection of $80.65 \%$ or 25 titles, a collection of historical types $16.13 \%$ or 5 titles, and a collection of criticism types only $3.23 \%$ or 1 title. The multidisciplinary field in the UNILAK FIB Library, the Sociology collection $83.33 \%$ or 10 titles, the type of psychology $0.00 \%$ or 0 titles, and the collection of anthropological types only $16.67 \%$ or 2 titles. While from the use of the collection of Literary works in the UNILAK FIB Library, from 400 titles (9.5\%) and 766 copies (13.8\%). The total usage of the collection of literary works is $16.19 \%$ or 124 times the
\end{abstract}


usage. Judging from the creative literature of the 95 types of prose titles used or $76.61 \%$ and poetry types only 8 titles or $6.45 \%$ and the drama no titles used at all. Judging from the use of scientific literary works in the field of monodisciplinary science 19 titles are used or $15.32 \%$ and in the multidisciplinary field, only 2 titles are used or 1.61\%.

\section{Keywords: Map, Suitability, Literary Work, FIB Library}

\section{PENDAHULUAN}

Koleksi merupakan komponen yang penting dalam sebuah perpustakaan. Tampa koleksi kegiatan layana di perpustakaan tak dapat berlaku sebagai mana mestinya Koleksi atau sumber informasi perpustakaan merupakaan salah satu pilar atau kekuatan dan daya tarik utama bagi pengunjung. Oleh sebab itu agar pilar tersebut kuat maka koleksi perpustakaan juga harus kuat, dalam pengertian dalam hal jumlah, jenis, ragam, dan mutu (NS, 2010). Salah satu jenis koleksi yang ada di perpustakaan yaitu koleksi karya, karya sastra pada hakikatnya adalah replika kehidupan nyata. Walaupun berbentuk fiksi, seperti cerpen, novel, dan drama, persoalan yang disodorkan oleh pengarang tak terlepas dari pengalaman kehidupan nyata sehari-hari. Hanya saja dalam penyampaiannya, pengarang sering mengemasnya dengan gaya yang berbeda-beda dan syarat pesan moral bagi kehidupan manusia (Sehandi, 2014: 2). Sastra merupakan suatu bentuk dan hasil pekerjaan seni kreatif yang objeknya adalah manusia dan kehidupannya dengan menggunakan bahasa sebagai mediumnya. Sebagai karya kreatif, sastra harus mampu melahirkan suatu kreasi yang indah dan berusaha menyalurkan kebutuhan keindahan manusia (Sehandi, 2014: 1).

Menurut Sehandi, (2014: 1), perwujudan sastra dalam perkembanganya berupa (1) karya sastra atau sastra kreatif, yang meliputi prosa, puisi, dan drama (2) ilmu sastra atau sastra ilmiah, yang meliputi bidang kajian monodisiplin, yang terdiri dari teori sastra, kritik sastra, dan bidang kajian yang bersifat multi disiplin, yang terdiri dari sosiologi sastra, piskologi sastra, dan antropologi sastra. Adapun 3 Peran koleksi sastra (1) sebagai sarana hiburan. Sastrawan menciptakan sastra antra lain sebagai sarana untuk menghibur orang lain, para penikmat atau pembasca; (2) sebagai ekpresi keindahan. Menentramkan dan menggembirakannya, karena di dalamnya manusia mengenali hubungan yang akrab antara dirinya dan hangat antara dirinya dengan sumber atau asas dengan segala sesuatu yang menarik, mengikat, menikmat dan memangil manusia untuk selalu dekat dengan sang penciptanya; (3) selain untuk hiburan juga bisa digunkan untuk pendidikan. Pendidikan yang di maksud disini yang bersifat tidak langsung atau informal. Karya yang diciptakan disini untuk mengemukakan nilai-nilai, pesan, cita-cita, serta pikiran dan perasaan yang terkandung dalam batinnya. Seorang pengarang menciptakan karya sastra karena ada sesuatu yang ingin di sampaikan kepada pembaca (Sehandi, 2014: 2).

Keberadaaan koleksi karya sastra sebagai salah satu wujud terselenggranya fungsi perpustakaan sekolah yaitu sebagi fungsi rekreasi. Artinya kolekis sastra dengan content yang ringan mampu menghibur pemustaka dalam mengakses informasi. Hal ini sesuai dengan pendapat Warren dalam (Nurgiyantoro, 2010:3) yang menyatakan bahwa membaca sebuah karya sastra fiksi berarti menikmati cerita dan menghibur diri untuk memperoleh kepuasan batin. Selain itu dengan adanya koleksi sastra di perpustakaan mampu memberikan daya tarik tersendiri bagi pemustaka, baik dalam kunjungan maupun minat baca pemustaka.

Perpustakaan FIB merupakan salah satu perpustakaan perguruan tinggi yang ada di lingkungan Universitas Lancang Kuning, prodi yang dilayani terdiri dari Prodi Sastra Daerah/ Melayu, Prodi Sastra Inggris, Sastra Indonesia, dan Ilmu Perpustakaan. Berdasarkan hasil pengamatan di lapangan ditemukan bahwa jumlah keseluruhan koleksi perpustakaan FIB berjumlah 4219 judul dengan 5565 eksemplar. Sedangkan untuk karya sastra berjumlah 400 judul dan 766 eksemplar. Jika di presentasikan jumlah judul koleksi karya sastra yaitu 9,5\%, dan jika di lihat dari jumlah exsemplarnya berjumlah $13,8 \%$

Selanjutnya peta atau pemetaan dalam kamus Bahasa Indonesia adalah suatu gagasan atau perasaan dengan menggunakan gambar, tulisan, peta, atau grafik. Sementara itu Spasser dalam Uli (2012: 1) dalam Nora (2015: 13), mengatakan bahwa "peta adalah alat relasi (relational tools) yang menyediakan informasi antar hubungan entitas yang dipetakan. Kedua pendapat ini tidak berbeda melainkan saling melengkapi, karena sebuah produk atau output pemetaan dihasilkan melalui proses. Sehingga 
dapat disimpulkan bahwa pemetaan adalah sebuah proses yang memungkinkan seseorang mengenali elemen pengetahuan serta konfigurasi, dinamika, ketergantungan timbal balik dan interaksinya.

Keterpakaian dalam Kamus Besar Bahasa Indonesia ( Suharso, 2016: 351) "keterpakaian" mempunyai makna guna atau manfaat. Jadi dapat disimpulkan bahwa "keterpakaian" adalah sesuatu yang bisa digunakan oleh penggunanya. Dengan keberadaan koleksi karya sastra serta dengan melihat jumlah koleksi sastra yang ada, maka perlu di lakukan sebuah evaluasi dalam bentuk peta dan keterpakaian karya sastra. Bedasarakan latar belakang di atas maka penulis ingin akan membahas lebih lanjut tentang bagaimana Peta dan keterpakaian karya sastra di Perpustakaan Fakultas Ilmu Budaya Unuversitas Lancang Kuning, dan bagaimana Pemanfaatan karya sastra di Perpustakaan Fakultas Ilmu Budaya Universitas Lancang Kuning. Sedangkan tujuan penelitian ini adalah untuk mengetahui bagaiman peta dan keterpakaian koleksi karya sastra dan pemanfaatannya di perpustakaan Fakultas Ilmu Budaya

\section{LANDASAN TEORI}

\section{Koleksi}

Koleksi perpustakaan adalah bahan pustaka yang dihimpun oleh suatu perpustakaan disediakan bagi masyarakat yang berminat memanfaatkannya. (Hermawan dan Zulfikar Zen, 2010: 31). Koleksi perpustakaan meliputi:

a. Buku (buku teks, buku penunjang kurikulum, buku bacaan, buku referensi dan buku biografi);

b. Terbitan berkala (majalah, suratkabar);

c. Audiovisual;

d. Layanan teknologi informasi dan komunikasi.

Jenis-jenis Koleksi Perpustakaan :

a. Koleksi Referensi, sumber informasi bersifat sekunder.

b. Koleksi Dewasa/Umum, koleksi berisi informasi dalam berbagai disiplin ilmu, terdiri dari buku teks dan penunjang.

c. Koleksi Remaja/Anak, koleksi umum terdiri dari buku fiksi dan nono fiksi.

d. Koleksi Serial, sumber informasi mutakhir dari terbitan berkala atau berseri (koran, jurnal, majalah, dll).

e. Koleksi Berbahasa Asing (bahasa Inggris dan bahasa Belanda) f. Bahan-bahan pandang dengar (audio visual)

\subsection{Pengertian Peta}

Dalam kamus bahasa Indonesia peta adalah suatu gagasan atau perasaan dengan menggunakan gambar, tulisan, peta, atau grafik. Sementara itu Spasser dalam Wahyuni (2012:1), mengatakan bahwa "peta adalah alat relasi (relational tools) yang menyediakan informasi antar hubungan entitas yang dipetakan." Kedua pendapat ini tidak berbeda melainkan saling melengkapi, karena sebuah produk atau output pemetaan dihasilkan melalui proses. Sehingga dapat disimpulkan bahwa pemetaan adalah sebuah proses yang memungkinkan seseorang mengenali elemen pengetahuan serta konfigurasi, dinamika, ketergantungan timbal balik dan interaksinya.

\section{Jenis Model Peta}

\section{a. Peta Kronologis}

Menurut Sulistyo-Basuki dalam Wahyuni (2012: 16) , mengatakan bahwa Pemetaan Kronologis merupakan pemetaan yang memberikan urutan kronologis berbagai penemuan dalam bentuk yang berkaitan dengan interdependensi temporer dan logis. Hasilnya adalah representasi berbagai sumbangan pengetahuan yang mengarah teknologi mutakhir.

\section{b. Peta Kognitif}

Pengertian pemetaan kognitif menurut Sulistyo-Basuki dalam Wahyuni (2012: 17), bahwa "Pemetaan kognitif merupakan pemetaan yang berisikan metode presentasi pengetahuan personal, kemudian dikembangkan sebagai kerangka kerja pemikiran system dan kajian dinamika system."

\section{c. Peta Konseptual}

Menurut Sulistyo-Basuki dalam Wahyuni (2012: 20), bahwa "pemetaan konseptual dapat digunakan untuk memaparkan seluruh domain pengetahuan guna mengidentifkasikan bidang menarik. Objek pemetaan konseptual dapat berupa disiplin ilmiah atau teknologi atau domain interdislipiner". Dari pemaparan diatas dapat disimpulkan bahwa pemetaan konseptual adalah pemetaan yang berguna untuk memaparkan seluruh domain pengetahuan dan yang merupakan objek pemetaan konseptual berupa disiplin ilmiah atau teknologi atau domain interdisipliner. 


\section{Keterpakaian Kolesi}

Dalam Kamus Besar Bahasa Indonesia (2002: 410) "keterpakaian" mempunyai makna guna atau manfaat. Dapat disimpulkan bahwa "keterpakaian" adalah sesuatu yang bisa digunakan oleh penggunanya. Sedangkan keterpakaian koleksi dapat diartikan suatu bahan pustaka yang berisi informasi yang dapat dimanfaatkan atau digunakan oleh pengguna perpustakaan. Menurut Mount Sount Vincent University dalam Nora (2015: 22) mengemukakan bahwa ada beberapa teknik yang digunakan untuk mengukur tingkat keterpakaian koleksi yaitu, Memperhatikan tingkatan judul (Katalog perpustakaan, Bibliografi subjek, Review essays, Bibliografi khusus, Daftar ususlan dari staf pengajar), Sistem data perpustakaan mencakup keseluruhan juduldalam subjek tertentu yang berhubungan dengan pengadaan, frekuensi sirkulasi peminjamandan statistik silang layanan, Menguji secara langsung ke rak dan Survei pengguna tentang cakupan, kedalaman, kesesuaian, dan kemutakhiran koleksi.

\section{Karya Sastra}

Sastra adalah hasil karya seni para pengarang atau sastrawan, yang antara lain berupa prosa (cerita pendek dan novel), puisi, dan drama (naskah drama atau pementasan drama). Sastra adalah ilmu pengetahuan atau bidang ilmu yang mempelajari karya-karya sastra (prosa, puisi, dan drama), yang dikenal dengan nama ilmu sastra atau sastra ilmiah (Sehandi, 2014: 1). Secara etimologis (makna kata berdasarkan asal-usulnya), kata sastra dalam bahasa Indonesia berasal dari bahasa Sansekerta, sastra. Dalam bahasa sansekerta, kata sastra dibentuk dari akar kata sas- dan tra-. Akar kata sas-(dalam kata kerja turunan) menunjukkan arti mengarahkan, mengajar, memberi petunjuk atau instruksi, sedangkan akar kata -tra menunjukkan arti alat atau sarana. Dengan demikian, sastra dapat berarti alat untuk mengajar, buku petunjuk, buku instruksi atau buku pengajaran (Sehandi, 2014: 2)

Jenis karya sastra terdiri sastra kreatif adalah hasil karya seni para pengarang atau sastrawan, yang antara lain berupa prosa (cerita pendek dan novel), puisi, dan drama (naskah drama atau pementasan drama). (Sehandi, 2014: 6) dan Sastra Ilmiah adalah ilmu pengetahuan atau bidang ilmu yang mempelajari karya-karya sastra yang bersifat monodisiplin, yang terdiri atas teori sastra, kritik sastra, sejarah sastra, dan bidang kajian yang bersifat multidisiplin, yang terdiri atas sosiologi sastra, psikologi sastra, dan antropologi sastra. (Sehandi, 2014: 6)

\section{METODE}

Objek penilitian ini adalah koleksi karya sastra yang ada di Perpustakaan Fakultas Ilmu Budaya Universitas Lancang Kuning. Jenis penelitian yang digunakan adalah penelitian kualitatif. Data dikumpulkan melalui studi dokumentasi. Studi dokumentasi yang dimaksud adalah melakukan penelusuran koleksi di Perpustakaan FIB Universitas Lancang Kuning di bidang karya sastra yang ada pada SLIMS. Data yang diperoleh kemudian diinterpretasikan dengan mengelompokkanya berdasarkan jendre, ragam, dan jenis. Sedangkan populasi dalam penelitian ini adalah seluruh karya sastra yang berjumlah 400 judul buku dan 766 eksemplar.

\section{HASIL DAN PEMBAHASAN}

\section{Analisis Data Koleksi}

Koleksi karya sastra terdiri dari sastra dan sastra kreatif

Tabel 1. Koleksi Sastra Kreatif

\begin{tabular}{|c|l|c|c|}
\hline No & Jenis & F & $\mathbf{\%}$ \\
\hline 1 & Prosa & 241 & 67,51 \\
\hline 2 & Puisi & 95 & 26,6 \\
\hline 3 & Drama & 21 & 5,58 \\
\hline & Total & $\mathbf{3 5 7}$ & $\mathbf{1 0 0}$ \\
\hline
\end{tabular}

Sumber: data yang sudah di olah Oktober 2018

Tabel 2. Koleksi Sastra Ilmiah

\begin{tabular}{|c|l|c|c|}
\hline No & \multicolumn{1}{|c|}{ Jenis } & F & \% \\
\hline 1 & $\begin{array}{l}\text { Bidang } \\
\text { Monodisiplin }\end{array}$ & 31 & 72,09 \\
\hline 2 & $\begin{array}{l}\text { Bidang multi } \\
\text { Disiplin }\end{array}$ & 12 & 27,9 \\
\hline & \multicolumn{1}{|c|}{ Total } & $\mathbf{4 3}$ & $\mathbf{1 0 0}$ \\
\hline
\end{tabular}

Sumber: data yang sudah di olah oktober 2018

Koleksi Sastra bidang Monodisiplin merupakan Koleksi terbanyak yaitu 31 judul atau $72,09 \%$ sedangkan presentase koleksi sastra multididiplin rendah, yaitu 12 judul atau $27,91 \%$.

Tabel 3. Koleksi Sastra Prosa

\begin{tabular}{|c|c|c|c|}
\hline No & Jenis & $\mathbf{F}$ & $\mathbf{\%}$ \\
\hline 1 & Novel & 131 & 54,36 \\
\hline 2 & Cerpen & 110 & 45,64 \\
\hline & Total & $\mathbf{2 4 1}$ & $\mathbf{1 0 0}$ \\
\hline
\end{tabular}

Sumber: data yang sudah diolah Oktober 2018 Novel merupakan jenis koleksi terbanyak dengan presentase 131 judul atau 54,36\%, 
sedangkan presentase koleksi cerpen rendah, yaitu 110 judul atau 45,64\%

Tabel 4 Koleksi Bidang Monodisiplin

\begin{tabular}{|c|l|c|c|}
\hline No & Jenis & $\mathbf{F}$ & $\mathbf{\%}$ \\
\hline 1 & Teori & 25 & 80,65 \\
\hline 2 & Sejarah & 5 & 16,13 \\
\hline 3 & Kritik & 1 & 3,23 \\
\hline & Total & $\mathbf{3 1}$ & $\mathbf{1 0 0}$ \\
\hline
\end{tabular}

Suber: data yang sudah diolah Oktober 2018

Teori merupakan jenis koleksi terbanyak yaitu 25 judul atau 80,65\%, sedangkan presentase koleksi jenis sejarah dan kritik sangat rendah, yaitu 5 judul atau 16,13\% dan $3,23 \%$.

\section{Tabel 5. Koleksi Sastra Multidisiplin}

\begin{tabular}{|c|l|c|c|}
\hline No & Jenis & F & $\mathbf{\%}$ \\
\hline 1 & Sosiologi & 10 & 83,33 \\
\hline 2 & Psikologi & 0 & 0,00 \\
\hline 3 & Antropologi & 2 & 16,67 \\
\hline & Total & 12 & 100,00 \\
\hline
\end{tabular}

Suber: data yang sudah di olah Oktober 2018

Sosiologi merupakan jenis koleksi terbanyak dengan presentase sangat tinggi yaitu, atau 10 judul 83,33\% sedangkan Piskologi presentase koleksi sangat rendah yaitu 0 judul $0,00 \%$ dan presentase Antropologi sangat rendah yaitu, 2 judul atau 16,67\%.

\section{Keterpakaian Koleksi Sastra}

Tabel 6. Keterpakaian Koleksi karya Sastra

\begin{tabular}{|c|l|c|c|}
\hline No & \multicolumn{1}{|c|}{ Jenis } & F & $\mathbf{\%}$ \\
\hline 1 & $\begin{array}{l}\text { Sastra } \\
\text { kreatif }\end{array}$ & 103 & 83,06 \\
\hline 2 & Sastra Ilmiah & 21 & 16,94 \\
\hline & Total & $\mathbf{1 2 4}$ & $\mathbf{1 0 0}$ \\
\hline
\end{tabular}

Sumber: data yang sudah di olah Oktober 2018

Keterpakaian koleksi karya sastra kreatif sangat tinggi yaitu 103 kali keterpakaian atau 83,06\% sedangkan keterpakaian koleksi jenis Sastra Ilmiah berada pada presentase sangat rendah, yaitu 21 kali keterpakaian atau 16.94\%. Tingkat keterpakaian jenis Sastra kreatif yaitu 51 judul koleksi dari 103 kali keterpakaian. Jika dilihat dari judul koleksi angka keterpakaian tertinggi yaitu koleksi dengan judul Precil tetap tinggal di danau dan Novel, Naskah Drama dan Telaah Burung Tiung Seri Gading dengan 6 kali keterpakaian atau 5,83\%, Pipit dan Manis Sahabat Sejati, Dikalahkan Sang Sapurba, konsisten dengan 5 kalai keterpakaian atau 4,85\%, Pipa Air Mata: Cerpen Pilihan Riau Pos 2008, Hempasan Gelombang dengan 4 kali keterpakaian atau 3,88\%, Percobaan Setia,
Republik Jangkrik, Gelombang Sunyi, Mengadili Sang Sapurba, Merbau Bersiram Darah, Pengkajian Puisi, Tunjuk Ajar Dalam Pantun Melayu dengan 3 kali keterpakaian atau 2,91\%, Perahu Tenggelam, Robohnya Surau Kami, Kemarau, Panggil Aku Sakai, Assalamualaikum Beijing, Katak Hendak Jadi Lembu dengan 2 kali keterpakain atau 1,94\%, Pelajaran Mengarang: Cerpen Pilihan Kompas 1993, Dua Tengkorak Kepala : Cerpen Pilihan Kompas 2000, Negeri Anyaman: Cerpen Pilihan Riau Pos 2010, Robohkan Lagi Pagar Itu, Datuk, Tunggu Aku Di Sungai Duku, Bapak: Jejak-jejak di Kebun Karet, Deja Vu, Dunia Sukab, Gempa Waktu, Ketika Cinta Bertasbih, Kopi Hujan Pagi, Mauve!, Mawar Biru Bintangku, Menentang Matahari, Mutiara di Kota Melbourne, Pohon-Pohon Sesawi, Pohon-Pohon Sesawi, Polo si Sopan, Seoul Cinderella, Tahun '69, Tenggelam, Akar, Atap, Ayat-ayat Cinta, Benang Merah Keajaiban, Berdialog dengan Kema, Bulang Cahaya : Sebuah Novel, Oknum-oknum, Yakuza Moon: Memoar Seorang Putri Gangster Jepang, Nyanyian Malam: Sajak-Sajak, Unjuk Ajar Melayu: Butirbutir Budaya Melayu Riau dengan 1 kali keterpakaian atau $0,97 \%$.

Tabel 7. Kerterpakaian Sastra Ilmiah Berdasarkan Judul Koleksi

\begin{tabular}{|c|l|c|c|}
\hline No & \multicolumn{1}{|c|}{ Judul koleksi } & F & \% \\
\hline 1 & Teori Pengkajian Fiksi Penelitian & 13 & 61,90 \\
\hline 2 & $\begin{array}{l}\text { Metodologi } \\
\text { Sosiologi Sastra }\end{array}$ & 2,52 \\
\hline 3 & Kritik Sastra & 9,52 \\
\hline 4 & $\begin{array}{l}\text { Teori, Metode, dan Teknik } \\
\text { Penelitian Sastra: Dari } \\
\text { Strukturalisme Hingga }\end{array}$ & 1 & 4,76 \\
\hline 5 & $\begin{array}{l}\text { Stilistika: kajian puitika } \\
\text { bahasa, sastra, dan budaya }\end{array}$ & 1 & 4,76 \\
\hline 6 & $\begin{array}{l}\text { Pengantar Sosiologi Sastra } \\
\text { dari Strukturalisme Genetik } \\
\text { sampai Postmodernisme }\end{array}$ & 1 & 4,76 \\
\hline 7 & Sosiologi Sastra & 1 & 4,76 \\
\hline & \multicolumn{2}{|l|}{} & \\
\hline
\end{tabular}

Sumber: data yang sudah di olah Oktober 2018

Berdasarkan tabel di atas dapat dilihat bahwa dari jumlah keseluruhan keterpakaian Sastra ilmiah yang ada di perpustakaan FIB UNILAK hanya 7 judul koleksi dari 21 kali keterpakaian. Jika dilihat dari keterpakaian berdasarkan judul koleksi, maka judul yang sering di pakai yaitu koleksi dengan judul Teori Pengkajian Fiksi 13 kali keterpakaian atau 61,90\%,Kritik Sastra, Metodologi Penelitian Sosiologi Sastra dengan 2 kali keterpakaian atau 9,52 \%, Stilistika: kajian puitika bahasa, sastra, dan budaya, Teori, Metode, dan Teknik Penelitian Sastra: Dari Strukturalisme Hingga, 
Sosiologi Sastra, Pengantar Sosiologi Sastra dari Strukturalisme Genetik sampai Postmodernisme dengan 1 kali keterpakaian.

Tabel 8. Kerterpakaian Koleksi Sastra Kreatif

\begin{tabular}{|c|l|c|c|}
\hline No & Jenis & F & $\mathbf{\%}$ \\
\hline 1 & Prosa & 95 & 91,35 \\
\hline 2 & Puisi & 9 & 8,65 \\
\hline 3 & Drama & 0 & 0 \\
\hline & Total & $\mathbf{1 0 3}$ & $\mathbf{1 0 0}$ \\
\hline
\end{tabular}

Sumber: data yang sudah di olah Oktober 2018

Berdasarkan tabel di atas dapat dilihat bahwa, keterpakaian koleksi sastra kreatif jenis prosa tingkat keterpakaian koleksinya sangat tinggi. Ha ini dapat buktikan dari peresentase 95 kali keterpakaian atau 91,35\%, sedangkan keterpakaian koleksi jenis puisi juga sangat rendah yaitu, 9 kali keterpakaian atau 8,65\%, dan jenis koleksi drama juga sangat Rendah yaitu 0 kali keterpakaian atau.

Tabel 9. Kerterpakaian Berdasarkan Judul Koleksi Sastra Jenis Prosa

\begin{tabular}{|c|l|c|c|}
\hline No & \multicolumn{1}{|c|}{ Judul keterpakaian } & F & \% \\
\hline 1 & Precil tetap tinggal di danau & 6 & 6,32 \\
\hline 2 & $\begin{array}{l}\text { Novel, Naskah Drama dan Telaah Burung } \\
\text { Tiung Seri Gading }\end{array}$ & 6 & 6,32 \\
\hline 3 & Murai malam dan pelangi pagi & 5 & 5,26 \\
\hline 4 & Dikalahkan sang Sapurba & 5 & 5,26 \\
\hline 5 & Konsisten & 5 & 5,26 \\
\hline 6 & Pipit dan manis sahabat sejati & 5 & 5,26 \\
\hline 7 & Pipa air mata: Cerpen pilihan RIau Pos & 4 & 4,21 \\
\hline 8 & Heo8 & 4 & 4,21 \\
\hline 9 & Republik jangkrik & 3 & 3,16 \\
\hline 10 & Gelombang sunyi & 3 & 3,16 \\
\hline 11 & Merbau bersiram darah & 3 & 3,16 \\
\hline 12 & Percobaan Setia & 3 & 3,16 \\
\hline 13 & Mengadili Sang Sapurba & 3 & 3,16 \\
\hline 14 & Panggil Aku Sakai & 2 & 2,11 \\
\hline 15 & Assalamualaikum Beijing & 2 & 2,11 \\
\hline 16 & Perahu tenggelan & 2 & 2,11 \\
\hline 17 & Kemarau & 2 & 2,11 \\
\hline 18 & Robohnya Surau Kami & 2 & 2,11 \\
\hline 19 & Katak hendak jadi lembu & 2 & 2,11 \\
\hline 20 & Robohkan Lagi Pagar Itu, Datuk & 1 & 1,05 \\
\hline 21 & Bapak: Jejak-jejak di Kebun Karet & 1 & 1,05 \\
\hline 22 & Tunggu Aku Di Sungai Duku & 1 & 1,05 \\
\hline 23 & Deja vu & 1 & 1,05 \\
\hline 24 & $\begin{array}{l}\text { Pelajaran Mengarang: Cerpen Pilihan } \\
\text { Kompas 1993 }\end{array}$ & 1 & 1,05 \\
\hline 25 & Dunia sukab & 1 & 1,05 \\
\hline 26 & Gempa Waktu & 1 & 1,05 \\
\hline 27 & Kopi Hujan Pagi & 1 & 1,05 \\
\hline 28 & Ketika Cinta Bertasbih & 1,05 \\
\hline 29 & Mauve! & 1,05 \\
\hline
\end{tabular}

\begin{tabular}{|l|l|c|c|}
30 & Mawar biru bintangku & 1 & 1,05 \\
\hline 31 & Menentang Matahari & 1 & 1,05 \\
\hline 32 & $\begin{array}{l}\text { Negeri Anyaman:Cerpen Pilihan Riau Pos } \\
2010\end{array}$ & 1 & 1,05 \\
\hline 33 & Pohon-Pohon Sesawi & 1 & 1,05 \\
\hline 34 & Pohon-Pohon SesawiPolo si sopan & 1 & 1,05 \\
\hline 35 & Seoul Cinderella & 1 & 1,05 \\
\hline 36 & Tahun '69 & 1 & 1,05 \\
\hline 37 & Tenggelam & 1 & 1,05 \\
\hline 38 & Akar & 1 & 1,05 \\
\hline 39 & $\begin{array}{l}\text { Dua Tengkorak kepala : Cerpen Pilihan } \\
\text { Kompas 2000 }\end{array}$ & 1 & 1,05 \\
\hline 40 & Atap & 1 & 1,05 \\
\hline 41 & Ayat-ayat Cinta & 1 & 1,05 \\
\hline 42 & Benang Merah keajaiban & 1 & 1,05 \\
\hline 43 & Berdialog dengan Kema & 1 & 1,05 \\
\hline 44 & Deja vu & 1 & 1,05 \\
\hline 45 & Bulang Cahaya : sebuah novel & 1 & 1,05 \\
\hline 46 & Mutiara Di kota Melbourne & 1 & 1,05 \\
\hline 47 & $\begin{array}{l}\text { Yakuza moon: Memoar seorang putri } \\
\text { gangster Jepang }\end{array}$ & 1 & 1,05 \\
\hline \multicolumn{2}{|c|}{ Total } & $\mathbf{9 5}$ & $\mathbf{1 0 0}$ \\
\hline
\end{tabular}

Sumber: data yang sudah di olah oktober 2018

Berdasarkan tabel di atas dapat dilihat bahwa tingkat keterpakaian koleksi sastra dari jenis prosa yang ada di Perpustakaan FIB UNILAK, hanya 47 judul koleksi dari 95 kali keterpakaian. Jika dilihat dari keterpakaian berdasarkan judul koleksi. Maka judul yang sering dipakai yaitu koleksi dengan judul Precil Tetap Tinggal di Danau, novel, naskah drama dan Telaah Burung Tiung Seri Gading dengan 6 kali keterpakaian atau 6,32\%, Pipit dan manis sahabat sejati, Dikalahkan Sang Sapurba, Konsisten, Murai malam dan pelangi pagi dengan 5 kali keterpakian atau 5,26\%, Hempasan Gelombang, Pipa air mata: Cerpen pilihan Riau Pos dengan 4 kali keterpakaian atau 4,21\%, Merbau Bersiram Darah, Republik Jangkrik, Gelombang Sunyi, Mengadili Sang Sapurba, Percobaan Setia dengan 3 kali keterpakaian atau 3,16\%, Perahu Tenggelan, Robohnya Surau Kami, Kemarau, Panggil Aku Sakai, Assalamualaikum Beijing, Katak Hendak Jadi Lembu dengan 2 kali keterpakaian atau 2,11\%, Dua Tengkorak Kepala : Cerpen Pilihan Kompas 2000, Negeri Anyaman:Cerpen Pilihan Riau Pos 2010, Pelajaran Mengarang: Cerpen Pilihan Kompas 1993,Robohkan Lagi Pagar Itu, Datuk, Tunggu Aku di Sungai Duku, Bapak: Jejak-jejak di Kebun Karet, Deja vu, Dunia Sukab, Gempa Waktu, Ketika Cinta Bertasbih, Kopi Hujan Pagi, Mauve!, Mawar Biru Bintangku, Menentang Matahari, Mutiara di Kota Melbourne, Pohon-Pohon Sesawi, Polo Si Sopan, Seoul Cinderella, Tahun '69, Tenggelam, Akar, Atap, Ayat-ayat Cinta, Benang Merah Keajaiban, Berdialog dengan Kema, Bulang Cahaya: Sebuah 
novel, Oknum-oknum, Yakuza Moon: Memoar Seorang Putri Gangster Jepang dengan 1 kali keterpakaian atau 1,05\%.

Tabel 10.1 Kerterpakaian Berdasarkan Judul Koleksi Sastra

\begin{tabular}{|c|l|c|c|}
\hline No & \multicolumn{1}{|c|}{ Judul keterpakaian } & F & \% \\
\hline 1 & Pengkajian puisi & 3 & 37,5 \\
\hline 2 & Tunjuk ajar dalam pantun melayu & 3 & 37,5 \\
\hline 3 & $\begin{array}{l}\text { Tunjuk ajar melayu:Butir-butir } \\
\text { budaya melayu riau }\end{array}$ & 1 & 12,5 \\
\hline 4 & Nyanyian malam: sajak-sajak & 1 & 12,5 \\
\hline \multicolumn{2}{|c|}{ Total } & $\mathbf{8}$ & $\mathbf{1 0 0}$ \\
\hline
\end{tabular}

Sumber: data yang sudah di olah Oktober 2018

Berdasarkan tabel di atas dapat dilihat bahwa tingkat keterpakaian koleksi sastra kreatif jenis puisi 4 judul Koleksi dari 8 kali keterpakaian. Jika dilihat dari keterpakaian berdasarkan judul koleksi. Maka judul yang sering dipakai yaitu pengkajian puisi, Tunjuk Ajar dalam pantun Melayu dengan 3 kali keterpakaian 37,5\% , Tunjuk Ajar Melayu: Butirbutir budaya Melayu Riau, Nyanyian Malam: Sajak-Sajak dengan 1 kali keterpakaian atau $12,5 \%$.

Sedangkan tingkat keterpakaian koleksi sastra kreatif jenis Drama, keterpakaiannya 0 judul koleksi dari 0 keterpakaian. Dapat disimpulkan bahwa tidak adanya keterpakaian koleksi Sastra Kreatif jenis Drama di karenakan masih sangat minimnya judul koleksi saastra di jenis drama.

Tabel 11 Kerterpakaian Koleksi Sastra Ilmiah

\begin{tabular}{|c|l|c|c|}
\hline No & \multicolumn{1}{|c|}{ Jenis } & F & $\mathbf{\%}$ \\
\hline 1 & $\begin{array}{l}\text { Bidang } \\
\text { Monodisiplin }\end{array}$ & 19 & 90,48 \\
\hline 2 & $\begin{array}{l}\text { Bidang } \\
\text { multidisiplin }\end{array}$ & 2 & 9,52 \\
\hline & \multicolumn{1}{|c|}{ Total } & $\mathbf{2 1}$ & $\mathbf{1 0 0 , 0 0}$ \\
\hline
\end{tabular}

Sumber: data yang sudah di olah oktober 2018

Berdasarkan tabel di atas dapat dilihat bahwa keterpakaian koleksi Sastra dibidang Monodisiplin 90,48\% atau 19 kali keterpakaian sedangkan jenis koleksi sastra multididisiplin 9,52\% atau 2 keterpakaian

Tabel 12. Kerterpakaian Berdasarkan Judul Koleksi Sastra Ilmiah Bidang Monodisiplin

\begin{tabular}{|c|l|c|c|}
\hline No & \multicolumn{1}{|c|}{ Judul keterpakaian } & F & \% \\
\hline 1 & Teori pengkajian fiksi & 13 & 68,42 \\
\hline 2 & Kritik Sastra & 2 & 10,53 \\
\hline 3 & $\begin{array}{l}\text { Metodologi Penelitian Sosiologi } \\
\text { Sastra }\end{array}$ & 2 & 10,53 \\
\hline
\end{tabular}

\begin{tabular}{|c|l|c|c|}
4 & $\begin{array}{l}\text { Stilistika: kajian puitika bahasa, } \\
\text { sastra, dan budaya }\end{array}$ & 1 & 5,26 \\
\hline 5 & $\begin{array}{l}\text { Teori, Metode, dan Teknik Penelitian } \\
\text { Sastra: Dari Strukturalisme Hingga }\end{array}$ & 1 & 5,26 \\
\hline & Total & $\mathbf{1 9}$ & $\mathbf{1 0 0}$ \\
\hline
\end{tabular}

Sumber: data yang sudah di olah Oktober 2018

Berdasarkan tabel di atas dapat dilihat bahwa tingkat keterpakaian koleksi sastra Ilmiah jenis bidang Monodisiplin, hanya 5 judul koleksi dari 19 kali keterpakaian. Kamus istilah sastra 13 kali keterpakain atau 68,42\%, kritik sastra, metodologi penelitian sosiologi sastra 2 dengan 2 kali keterpakaian 10,53\%,Teori, Metode, dan Teknik Penelitian Sastra: Dari Strukturalisme Hingga, Stilistika: kajian puitika bahasa, sastra, dan budaya dengan 1 kali keterpakaian atau 5,26\%. Daari 19 kali keterpakaian secara keseluruhan.

Jika dilihat dari keterpakaian berdasarkan judul koleksi. Maka judul yang sering dipakai yaitu Teori pengkajian fiksi dengan 13 kali keterpakaian atau 68,42\%.

Tabel 13 Kerterpakaian Berdasarkan Judul Koleksi Sastra Ilmiah

\begin{tabular}{|c|l|c|c|}
\hline No & \multicolumn{1}{|c|}{ Judul keterpakaian } & F & $\mathbf{\%}$ \\
\hline 1 & $\begin{array}{l}\text { Pengantar Sosiologi Sastra } \\
\text { dari Strukturalisme Genetik } \\
\text { sampai Postmodernisme }\end{array}$ & 1 & 50 \\
\hline 2 & Sosiologi Sastra & 1 & 50 \\
\hline & Total & 2 & 100 \\
\hline
\end{tabular}

Sumber: data yang sudah di olah Oktober 2018

Berdasarkan tabel di atas dapat dilihat bahwa tingkat keterpakaian koleksi sastra ilmiah jenis bidang multidisiplin yang ada di Perpustakaan FIB UNILAK. Hanya 2 judul koleksi dari 2 kali keterpakaian Jika di lihat dari keterpakaian berdasarkan judul koleksi. Maka judul yang sering di pakai yaitu, Pengantar Sosiologi Sastra dari Strukturalisme Genetik sampai Postmodernisme dengan 1 kali keterpakaian $50 \%$ dan Sosiologi Sastra dengan 1 kali keterpakaian atau 50\%. Hasil wawancara menyimpulkan bahwa semua keterpakaian koleksi di Perpustakaan FIB UNILAK di karnakan adanya tugas dari dosen perkuliahan

Tabel 24 Kerterpakaian Koleksi Sastra Prosa

\begin{tabular}{|c|c|c|c|}
\hline No & Jenis & $\mathbf{F}$ & $\mathbf{\%}$ \\
\hline 1 & Novel & 62 & 65,26 \\
\hline 2 & Cerpen & 33 & 34,74 \\
\hline & Total & $\mathbf{9 5}$ & $\mathbf{1 0 0}$ \\
\hline
\end{tabular}

Sumber:Data yang sudah di olah oktober 2018

Berdasarkan tabel di atas dapat dilihat bahwa, keseluruhan keterpakaian sastra novel 
berada di presentase tinggi yaitu 62 kali keterpakaianatau 65,26\%. Sedangkan keterpakaian koleksi cerpen berada di presentase rendah yaitu 33 kali keterpakaian atau $34,74 \%$,

Informan 1 mengatakan bahwa "jemisjenis koleksi sastra kreatif lebih banyak digunakan karena jumlahnya lebih banyak di Perpustakan dan di lihat juga dari jenis sasrta kreatif. prosa lebih banyak dari jenis sastra kereatif yang ada di Perpustakaan". Tingkat keterpakaian dari tabel di atas di pengaruhi oleh jumlah koleksi sastra prosa jenis novel yaitu 131 judul atau 54,36\% dan Cerpen 110 judul atau $45,64 \%$. Hal tersebut bisa di lihat dari tabel keterpakaian koleksi Karya Sastra prosa sesuai jenisnya dapat di lihat dari tabel berikit ini.

Tabel 14 Kerterpakaian Judul Koleksi Sastra Prosa Jenis Novel

\begin{tabular}{|c|l|c|c|}
\hline No & \multicolumn{1}{|c|}{ Judul keterpakaian } & F & $\mathbf{\%}$ \\
\hline 1 & $\begin{array}{l}\text { Novel, Naskah Drama dan Telaah } \\
\text { Burung Tiung Seri Gading }\end{array}$ & 6 & 9,68 \\
\hline 2 & Dikalahkan sang Sapurba & 5 & 8,06 \\
\hline 3 & Konsisten & 5 & 8,06 \\
\hline 4 & Murai malam dan pelangi pagi & 5 & 8,06 \\
\hline 5 & Hempasan Gelombang & 4 & 6,45 \\
\hline 6 & Mengadili Sang Sapurba & 3 & 4,84 \\
\hline 7 & Gelombang sunyi & 3 & 4,84 \\
\hline 8 & Merbau bersiram darah & 3 & 4,84 \\
\hline 9 & Kemarau & 2 & 3,23 \\
\hline 10 & Assalamualaikum Beijing & 2 & 3,23 \\
\hline 11 & Panggil Aku Sakai & 2 & 3,23 \\
\hline 12 & Mawar biru bintangku & 1 & 1,61 \\
\hline 13 & Menentang Matahari & 1 & 1,61 \\
\hline 14 & Kopi Hujan Pagi & 1 & 1,61 \\
\hline 15 & Ketika Cinta Bertasbih & 1 & 1,61 \\
\hline 16 & Gempa Waktu & 1 & 1,61 \\
\hline 17 & Mutiara Di kota Melbourne & 1 & 1,61 \\
\hline 18 & Mauve! & 1 & 1,61 \\
\hline 19 & Deja vu & 1 & 1,61 \\
\hline 20 & Pohon-Pohon Sesawi & 1 & 1,61 \\
\hline 21 & Pohon-Pohon SesawiPolo si sopan & 1 & 1,61 \\
\hline 22 & Seoul Cinderella & 1 & 1,61 \\
\hline 23 & Tahun '69 & 1 & 1,61 \\
\hline 24 & Tenggelam & 1 & 1,61 \\
\hline 25 & Akar & 1 & 1,61 \\
\hline 26 & Dunia sukab & 1 & 1,61 \\
\hline 27 & Atap & 1 & 1,61 \\
\hline 28 & Ayat-ayat Cinta & 1 & 1,61 \\
\hline 29 & Benang Merah keajaiban & 1 & 1,61 \\
\hline 30 & Berdialog dengan Kema & 1 & 1,61 \\
\hline 31 & Bulang Cahaya : sebuah novel & 1 & 1,61 \\
\hline 32 & Oknum-oknum & 1 & 1,61 \\
\hline 33 & $\begin{array}{l}\text { Yakuza moon: Memoar seorang putri } \\
\text { gangster Jepang }\end{array}$ & 1 & 1,61 \\
\cline { 2 - 4 } & & $\mathbf{6 2}$ & $\mathbf{1 0 0}$ \\
\hline & & \\
\hline
\end{tabular}

Sumber: data yang sudah di Olah oktober 2018
Berdasarkan tabel di atas dapat dilihat bahwa tingkat keterpakaian judul koleksi sastra prosa jenis novel yang ada di Perpustakaan FIB UNILAK. Hanya 33 judul koleksi dari 62 kali keterpakaian keterpakaian jika dilihat dari keterpakaian berdasarkan judul koleksi. Maka judul yang sering dipakai yaitu Novel, Naskah Drama dan Telaah Burung Tiung Seri Gading dengan 6 kali keterpakaian atau 9,68\%, dikalahkan sang Sapurba, Murai Malam dan Pelangi pagi 5 kali keterpakaian atau 8,06\%, Hempasan Gelombang 4 kali keterpakaian atau $6,45 \%$, Gelombang sunyi, Mengadili Sang Sapurba, Merbau bersiram darah dengan $3 \mathrm{kali}$ keterpakaianatau 4,84\% dari 33 judul 62 kali keterpakaian secara keseluruhan. Dari hasil wawancara dapat disimpulkan bahwa semua keterpakaian koleksi di Perpustakaan FIB UNILAK di karnakan adanya tugas dari dosen perkuliahan dan dan selain itu untuk menyelesaikan tugas akhir atau skripsi.

Tabel 15. Kerterpakaian Judul Koleksi Sastra Prosa Jenis Cerpen

\begin{tabular}{|c|l|c|c|}
\hline No & \multicolumn{1}{|c|}{ Judul keterpakaian } & F & \% \\
\hline 1 & Precil tetap tinggal di danau & 6 & 18,18 \\
\hline 2 & Pipit dan manis sahabat sejati & 5 & 15,15 \\
\hline 3 & $\begin{array}{l}\text { Pipa air mata: Cerpen pilihan RIau Pos } \\
\text { 2008 }\end{array}$ & 4 & 12,12 \\
\hline 4 & Percobaan Setia & 3 & 9,09 \\
\hline 5 & Republik jangkrik & 3 & 9,09 \\
\hline 6 & Perahu Tenggelam & 2 & 6,06 \\
\hline 7 & Robohnya Surau Kami & 2 & 6,06 \\
\hline 8 & Katak hendak jadi lembu & 2 & 6,06 \\
\hline 9 & $\begin{array}{l}\text { Dua Tengkorak kepala : Cerpen Pilihan } \\
\text { Kompas 2000 }\end{array}$ & 1 & 3,03 \\
\hline 10 & $\begin{array}{l}\text { Pelajaran Mengarang: Cerpen Pilihan } \\
\text { Kompas 1993 }\end{array}$ & 1 & 3,03 \\
\hline 11 & Robohkan Lagi Pagar Itu, Datuk & 1 & 3,03 \\
\hline 12 & $\begin{array}{l}\text { Negeri Anyaman:Cerpen Pilihan Riau } \\
\text { Pos 2010 }\end{array}$ & 1 & 3,03 \\
\hline 13 & Tunggu Aku Di Sungai Duku & 1 & 3,03 \\
\hline 14 & Bapak: Jejak-jejak di Kebun Karet & 1 & 3,03 \\
\hline & \multicolumn{10}{|c|}{ Total } & $\mathbf{1 0 0}$ \\
\hline
\end{tabular}

Sumber: data yang sudah di olah oktober 2018

Berdasarkan tabel di atas dapat dilihat bahwa tingkat keterpakaian judul koleksi sastra prosa jenis cerpen yang ada di Perpustakaan FIB UNILAK. Hanya 14 judul koleksi dari 33 kali keterpakaian. Jika dilihat dari keterpakaian berdasarkan judul koleksi. Maka judul yang sering dipakai yaitu Precil Tetap Tinggal di Danau dengan 6 kali keterpakaian atau 18,18\%, Pipit dan manis sahabat sejati dengan $\quad 5$ kali keterpakaian atau $15,15 \%$, Pipa air mata: Cerpen pilihan RIau Pos 2008 dengan 4 kali 
keterpakaian atau 12,12\%, Republik jangkrik, Percobaan Setia dengan 3 kali keterpakaian atau 9,09\%, Katak hendak jadi lembu, Robohnya Surau Kami, Perahu tenggelan dengan 2 kali keterpakaian atau 6,06\% dan Dua Tengkorak kepala : Cerpen Pilihan Kompas 2000, Negeri Anyaman:Cerpen Pilihan Riau Pos 2010, Pelajaran Mengarang: Cerpen Pilihan Kompas 1993, Robohkan Lagi Pagar Itu, Datuk, Tunggu Aku Di Sungai Duku, Bapak: Jejak-jejak di Kebun Karetdengan 1 kali keterpakaian atau 3,03\%. dari jumlah keseluruhan. Dapat di simpulkan bahwa semua keterpakaian koleksi di Perpustakaan FIB UNILAK di karnakan adanya tugas dari dosen perkuliahan dan dan selain itu untuk menyelesaikan tugas akir atau skripsi.

Tabel 16. Kerterpakaian Koleksi Bidang Monodisiplin

\begin{tabular}{|c|l|c|c|}
\hline No & Jenis & $\mathbf{F}$ & $\mathbf{\%}$ \\
\hline 1 & Teori & 17 & 89,47 \\
\hline 2 & Sejarah & 0 & 0,00 \\
\hline 3 & Kritik & 2 & 10,53 \\
\hline & Total & $\mathbf{1 9}$ & $\mathbf{1 0 0}$ \\
\hline
\end{tabular}

Sumber: data yang sudah diolah )ktober 2018

Berdasarkan tabel di atas dapat dilihat bahwa, keseluruhan keterpakaian koleksi Sastra Bidang Monodisiplin yang ada di Perpustakaan FIB pada tahun 2018. jenis teori tingkat keterpakaian koleksinya sangat tingi di Perpustakaan. Hal ini dapat di buktikan daari presentase $89,47 \%$ atau 17 kali keterpakaian, sedangkan keterpakaian koleksi jenis Sejarah berada di presentase sangat rendah yaitu $0,00 \%$ atau 0 kali keterpakaian, dan keterpakaian koleksi jenis kritik berada di presentae sangat rendah yaitu $10,53 \%$ atau 2 kali keterpakaian.

Tabel 3. Kerterpakaian Sastra Ilmiah Berdasarkan Judul Bidang Monodisiplin Jenis Teori

\begin{tabular}{|c|c|c|c|}
\hline No & Judul keterpakaian & $\mathbf{F}$ & $\%$ \\
\hline 1 & Teori pengkajian fiksi & 13 & 76,47 \\
\hline 2 & $\begin{array}{lll}\text { Metodologi Penelitian } & \text { Sosiologi } \\
\text { Sastra } & & \end{array}$ & 2 & 11,76 \\
\hline 3 & $\begin{array}{lrr}\text { Teori, Metode, dan } & \text { Teknik } \\
\text { Penelitian Sastra: } & \text { Dari } \\
\text { Strukturalisme Hingga } & \\
\end{array}$ & 1 & 5,88 \\
\hline 4 & $\begin{array}{l}\text { Stilistika: kajian puitika bahasa, } \\
\text { sastra, dan budaya }\end{array}$ & 1 & 5,88 \\
\hline & $\begin{array}{l}\text { Total } \\
\end{array}$ & 17 & 100 \\
\hline
\end{tabular}

Sumber: data yang sudah diolah Oktober 2018

Berdasarkan tabel di atas dapat dilihat bahwa tingkat keterpakaian judul koleksi Sastra Bidang Monodisiplin jenis teori yang ada di Perpustakaan FIB UNILAK. Hanya 4 judul koleksi dari 17 kali keterpakaian. jika dilihat dari keterpakaian berdasarkan judul koleksi.
Maka judul yang sering dipakai yaituteori pengkajian fiksi dengan 13 kali keterpakaian atau 76,47\%, Metodologi Penelitian Sosiologi Sastra 2 kali keterpakaian atau11,76\% Teori, Metode, dan Teknik Penelitian Sastra: Dari Strukturalisme Hingga, Stilistika: kajian puitika bahasa, sastra, dan budaya dengan 1 kali keterpakaian atau 5,88\%. .

Tabel 184 Kerterpakaian Koleksi Bidang Monodisiplin Jenis Kritik

\begin{tabular}{|c|c|c|c|}
\hline No & Judul keterpakaian & F & $\mathbf{\%}$ \\
\hline 1 & Kritik Sastra & 2 & 100 \\
\hline \multirow{2}{*}{ Total } & $\mathbf{2}$ & $\mathbf{1 0 0}$ \\
\cline { 2 - 4 } & &
\end{tabular}

Sumber: data yang sudah di olah oktober 2018

Berdasarkan tabel di atas dapat dilihat bahwa tingkat keterpakaian judul koleksi Sastra bidang monodisiplin jenis kritik yang ada di Perpustakaan FIB UNILAK. Hanya 1 judul koleksi dari 2 kali keterpakaian. ika di lihat dari keterpakaian berdasarkan judul koleksi. Maka judul yang sering dipakai yaitu kritik sastra dengan 2 kali keterpakaian atau 100\%

Tabel 19 Kerterpakaian Koleksi Sastra Multidisiplin.

\begin{tabular}{|c|l|c|c|}
\hline No & Jenis & F & \% \\
\hline 1 & Sosiologi & 2 & 100 \\
\hline 2 & Psikologi & 0 & 0,00 \\
\hline 3 & Antropologi & 0 & 0,00 \\
\hline & Total & $\mathbf{2}$ & $\mathbf{1 0 0}$ \\
\hline
\end{tabular}

Sumber: data yang sudah diolah Oktober 2018

Berdasarkan tabel di atas dapat dilihat bahwa, keseluruhan keterpakaian koleksi sastra bidang multidisiplin yang ada di Perpustakaan FIB pada tahun 2018. Sosiologi merupakan jenis keterpakaian koleksi sangat tinggi yang ada di Perpustakaan. Hal ini dapat di buktikan daari presentase $100,00 \%$ atau 2 lali. sedangkan Piskologi dan antropologi berada di presentase sangat rendah yaitu, $0,00 \%$ atau 0 kali keterpakaian. dan Antropologi 0,00\% atau 0 kali keterpakaian. Hal tersebut dapat di lihat dari tabel berikit ini

Tabel 205 Kerterpakaian Berdasarkan Judul Koleksi Bidang Multidisiplin Jenis Sosiologi Sastra

\begin{tabular}{|c|l|c|c|}
\hline No & \multicolumn{1}{|c|}{ Judul keterpakaian } & F & \% \\
\hline 1 & $\begin{array}{l}\text { Pengantar Sosiologi Sastra dari } \\
\text { Strukturalisme Genetik sampai } \\
\text { Postmodernisme }\end{array}$ & 1 & 50 \\
\hline 2 & Sosiologi Sastra & 1 & 50 \\
\hline & Total & $\mathbf{2}$ & $\mathbf{1 0 0}$ \\
\hline
\end{tabular}

Sumber: data yang sudah diolah Oktober 2018

Berdasarkan tabel di atas dapat dilihat bahwa tingkat keterpakaian judul koleksi sastra bidang multidisiplin jenis sosiologi sastra yang ada di perpustakaan FIB UNILAK. Hanya 2 judul 
koleksi dari 2 kali keterpakaian jika dilihat dari keterpakaian berdasarkan judul koleksi. Maka judul yang sering di pakai yaitu Pengantar Sosiologi Sastra dari Strukturalisme Genetik sampai Postmodernisme 1 kali keterpakaian atau $50 \%$ danSosiologi Sastra 1 kali keterpakaian $50 \%$

Untuk melihat data keterpakaian Karia Sastra Perpustakaan Fakultas Ilmu Budaya Universitas Lancang Kuning secara keseluruhan dapat dilihat dari tabel di abawah ini.

Tabel 61 Keterpakaian Karya Sastra Secara Keseluruhan

\begin{tabular}{|c|l|c|c|}
\hline No & Jenis Sastra & F & $\mathbf{\%}$ \\
\hline 1 & Prosa & 95 & 76,61 \\
\hline 2 & Puisi & 8 & 6,45 \\
\hline 3 & Drama & 0 & 0 \\
\hline 4 & Monodisiplin & 19 & 15,32 \\
\hline 5 & Multidisiplin & 2 & 1,61 \\
\hline & Total & $\mathbf{1 2 4}$ & $\mathbf{1 0 0}$ \\
\hline
\end{tabular}

Berdasarkan tabel di atas dapat dilihat bahwa dari jumlah keseluruhan keterpakaian koleksi karya sastra dari Febbruary sampai dengan Agustus 2018 yang ada di Perpustakaan FIB UNILAK. baik dalam bentuk jenis koleksi maupun daalam bidang koleksi sastra jenis prosa merupakan koleksi yang paling bayak di pakai yaitu dengan 95 judul kolesi dengan presentase tinggi yaitu $76,61 \%$, Jenis puisi hanya 8 judul koleksi dengan presentase sangat rendah yaitu $6,45 \%$, sedangkan drama 0 judul dengan presentase sangat rendah yaitu $0.00 \%$ dan jika di lihat dari bidang koleksi sastra bidang monodisiplin yaitu 19 judul dengan presentase sangat rendah yaitu $15,32 \%$ dan di bidang multidisiplin hanya 2 judul dengan presentse sangat rendah yaitu $1,61 \%$.

\section{SIMPULAN}

1. Peta koleksi karya sastra yang ada di Perpustakaan FIB Unilak terdiri dari sastra kreatif yaitu $89,25 \%$ dan sastra ilmiah $10,75 \%$. Jenis koleksi sastra ilmiah (Monodisiplin 72,09\% dan bidang multidisiplin 27,21\%). Dilihat dari genre koleksi Prosa, jenis Novel 54,36\%. Sastra ilmiah di bidang Monodisiplin, jenis Teori $80,65 \%$, jenis sejarah $16,13 \%$ sedangkan koleksi jenis kritik 3,23\%. Jika di lihat dari bidang Multidisiplin (koleksi Sosiologi 83,33\% dan jenis piskologi $0 \%$ dan koleksi jenis Antropoloigi 16,67\%).

2. Jika dilihat dari keterpakaian koleksi karya Sastra secara keseluruhan yaitu 16,19\% atau
124 kali keterpakaian. Sastra kreatif jenis prosa 95 judul yang di gunakan atau 76,61\% dan jenis puisi hanya 8 judul atau 6,45 \% dan drama tidak ada judul yang di pakai sama sekali. Dan dilihat ari kterpakaian karaia sastra ilmiah bidang ilmiah monidisiplin 19 judul yang di pakai atau 15,32\% dan bidang multidisiplin hanya 2 judulyang di pakai atau $1,61 \%$

Berdasarkan pengamataan dan penelitian yang dilakukan oleh penulis, ada pun saran yang dapat peneliti sampaikan yaitu :

1. Perpustakaaan FIB perlu menambah koleksi karya Sastranya Terutama di bidang Sastra Ilmiah baik itu buku-buku Teori Sastra, kritik, antropologi, piskologi Sastra ,karena jumlah judul buku dan eksemlarnya yang masih terlalu sedikit di perpustakaan dan harus melakukan pengadaan koleksi terutama di bidang koleksi sastra ilmiah

2. Diharapkan kepada dosen-dosen menganjurkan kepada mahasisiwa khususnya mahasiswa-mahiswa sastra mencari referensi tugas kuliah di perpustakaan sehingga meningkatkan minat baca mahiswa yang berkunjung ke perpustaakan.kurangnya koleksi sastrta ilmiah juga sangat mempengaruhi keterpakaian koleksi sastra yang ada di Perpustakaan Ilmu Budaya Universitas Lancang Kuning.

\section{DAFTAR PUSTAKA}

Depdiknas. (2004). Perpustakaan Perguruan Tinggi: Buku Pedoman, edisi ketiga. Jakarta: Depdiknas

Foldana, Hengky. (2016). Peta Keterpakaian Koleksi perpustakaan di lingkungan universitas lancang kuning tahun 2015. Pekanbaru universitas lancang Kuning.

Hermawan, Rachman dan Zulfikar Zen. 2010. Etika Kepustakawanan : Suatu Pendekatan Terhadap Kode Etik Pustakawan Indonesia. Jakarta: Sagung Seto

Kartini.(2017). Evaliuasi Ketidak Keterpakaian Koleksi Pada Layanan sirkulasi Sirkulasi di Perpustakaan Poltekses Kemenkes Riau

Mafar, Fiqru, Dkk. (2014). Peta penelitian Mahasiswa Fakultas Ilmu Budaya Universitas Lancang Kuning. Pekanbaru: Universitas Lancang Kuning 
Nopita, Nora (2015). Pemetaan Artikel Respuplica Di Perpustakaan Fakultas Hukum Universitas Lancang Kuning Periode 2009-2013 Skripsi, Pekanbaru: Universitas Lancang Kuning

NS, Sutarno. (2010). Perpustakaan dan Masyarakat. Yogyakarta: Andi Offset.

Nurgiyantoro, Burhan. 2002. Teori Pengkajian Fiksi. Yogyakarta : Gadjah Mada University Press.

Sehandi, Y. (2014). Mengenal 25 Teori Sastra. Yogyakarta: Ombak.

Semi, A. (1990). Metode Penelitian Sastra. Padang: Angkasa.
Soeatminah. (1992). Perpustakaan, kepustakaan dan Kepustakawan. Yogyakarta: Kanisius

Sugiono. (2009). Statistik Untuk Penelitian. Bandung: Alfabeta

Suharso dan Ana Retnoningsih. 2016. Kamus Besar Bahasa Indonesia. Semarang: Widya Karya

Wahyuni, Uli. 2012. Analisis Pemetaan (Knowledge Mapping) Pada Information Research an International Electonica Journal Tahun 2009-2011. Skripsi. Medan: Universitas Sumatera Utara

Zed, Mestika. 2008. Metode Penelitian Kepustakaan. Bandung: Remaja Rosdakarya 